\title{
Plasma Protein Cold Ethanol Fractionation
}

National Cancer Institute

\section{Source}

National Cancer Institute. Plasma Protein Cold Ethanol Fractionation. NCI Thesaurus.

Code C112939.

A multistep purification process that isolates plasma proteins based upon the differential solubility of proteins in ethanol solutions. 